\title{
EXISTENCE AND UNIQUENESS OF SOLUTIONS FOR FRACTIONAL ORDER $m$-POINT BOUNDARY VALUE PROBLEMS
}

\author{
Kamal Shah, Salman Zeb and Rahmat Ali Khan
}

Abstract. This paper deals with the existence of solutions for a class of fractional order differential equations having $m$-points boundary conditions involving the Caputo fractional derivative. Moreover the nonlinearity also depend on the Caputo fractional derivative. We obtain sufficient conditions for the existence and uniqueness of solutions via Schauder's fixed-point theorem and Banach contraction principle. We provide an example to illustrate the applicability of our results.

Mathematics subject classification (2010): 26A33, 34A37, 34B05.

Keywords and phrases: Fractional differential equations, $m$-point boundary value problems, Caputo fractional derivative, fixed point theorem, Green's function.

\section{REFERENCES}

[1] R. Hilfer, Applications of Fractional Calculus in Physics, World Scientific, Singapore, 2000.

[2] A. A. Kilbas, O. I. Marichev and S. G. Samko, Fractional Integrals and Derivatives (Theory and Applications), Gordon and Breach, Switzerland, 1993.

[3] A. A. Kilbas, H. M. SRivastava and J. J. Trujillo, Theory and Applications of Fractional Differential Equations, North-Holland athematics Studies, vol. 204, Elsevier, Amsterdam, 2006.

[4] K. S. Miller AND B. Ross, An Introduction to the Fractional Calculus and Fractional Differential Equations, Wiley, New York, 1993.

[5] I. Podlubny, Fractional Differential Equations, Mathematics in Science and Engineering, Academic Press, New York, 1999.

[6] A. Belarbi, M. Benchohra AND A. OUAHAB, Existence results for functional differential equations of fractional order, Appl. Anal., 85 (2006), 1459-1470.

[7] R. P. Agarwal, M. Benchohra And S. Hamani, Boundary value problems for differential inclusions with fractional order, Adv. Stud. Contemp. Math., 12 (2) (2008), 181-196.

[8] M. BENCHOHRA, J. R. GRAEF AND S. HAMANI, Existence results for boundary value problems with nonlinear fractional differential equations, Appl. Anal., 87 (2008), 851-863.

[9] M. BENCHOHRA, S. HAMANI AND S. K. NTOUYAS, Boundary value problems for differential equations with fractional order, Surv. Math. Appl., 3 (2008), 1-12.

[10] M. Benchohra, J. Henderson, S. K. Ntouyas, And A. Ouahab, Existence results for fractional order functional differential equations with infinite delay, J. Math. Anal. Appl., 332 (2008), 1340-1350.

[11] R. P. Agarwal, M. Benchohra And S. Hamani, Boundary value problems for fractional differential equations, Georgian Math. J., 12 (2009), 401-411.

[12] B. AhMAD AND J. J. NiETO, Existence results for nonlinear boundary value problems of fractional integrodifferential equations with integral boundary conditions, Bound. Value Probl. Art., 708576 (2009), pp. 11.

[13] B. AhMAD AND V. OTERO-EsPinAR, Existence of solutions for fractional differential inclusions with anti-periodic boundary conditions, Bound. Value Probl. Art., 625347 (2009), pp. 11.

[14] V. Lakshmikantham, S. Leela and J. Vasundhara, Theory of Fractional Dynamic Systems, Cambridge Academic Publishers, Cambridge, UK, 2009. 
[15] R. P. Agarwal, M. Benchohra and S. Hamani, A Survey on Existence Results for Boundary Value Problems of Nonlinear Fractional Differential Equations and Inclusions, Acta. Appl. Math., 109 (2010), 973-1033.

[16] X. SU AND S. ZHANG, Unbounded solutions to a boundary value problem of fractional order on the half-line, Comput. Math. Appl., 61 (2011), 1079-1087.

[17] M. BENCHOHRA, S. HAMANI AND S. K. NTOUYAS, Boundary value problems for differential equations with fractional order and nonlocal conditions, Nonlinear. Anal. Theo. Meth. Appl., 71 (2009), 2391-2396.

[18] B. AhmAD AND S. Sivasundaram, On four-point nonlocal boundary value problems of nonlinear integro-differential equations of fractional order, Appl. Math. Comput., 217 (2) (2010), 480-487.

[19] Z. BAI, On positive solutions of a nonlocal fractional boundary value problem, Nonlinear Anal. Theo. Meth. Appl., 72 (2) (2010), 916-924.

[20] M. El-Shahed AND J. J. Nieto, Nontrivial solutions for a nonlinear multi-point boundary value problem of fractional order, Comput. Math. Appl., 59 (11) (2010), 3438-3443.

[21] C. F. LI, X. N. LUO AND Y. ZHOU, Existence of positive solutions of the boundary value problem for nonlinear fractional differential equations, Comput. Math. Appl., 59 (3) (2010), 1363-1375.

[22] M. REHMAN AND R. A. KHAN, Existence and uniqueness of solutions for multi-point boundary value problems for fractional differential equations, Appl. Math. Lett., 23 (9) (2010), 1038-1044.

[23] W. ZHONG AND W. LiN, Nonlocal and multiple-point boundary value problem for fractional differential equations, Comput. Math. Appl., 59 (3) (2010), 1345-1351.

[24] M. El-SHAHED AND W. M. SHAMMAKH, Existence of positive solutions for m-point boundary value problem for nonlinear fractional differential equation, Abstr. Appl. Anal. vol. 2011 (2011), Article ID 986575, pp. 20.

[25] Z. CUI, P. YU AND Z. MAO, Existence of solutions for nonlocal boundary value problems of nonlinear fractional differential equations, Advanc. Dyn. Sys. Appl., 7 (1) (2012).

[26] R. A. KHAN, Three-point boundary value problems for higher order nonlinear fractional differential equations, J. Appl. Math. Inform., 31 (12) (2013), 221-228.

[27] A. M. A. EL-S AYED AND E. O. BIN-TAHER, Positive solutions for a nonlocal multi-point boundaryvalue problem of fractional and second order, Electr. J. Diff. Eqns., 64 (2013), 1-8.

[28] M. Benchohra, N. Hamidi and J. Henderson, Fractional differential equations with antiperiodic boundary conditions, Numerical Funct. Anal. Opti., 34 (4) (2013), 404-414.

[29] K. SHAH AND R. A. KHAN, Existence and uniquness of positive solutions to a coupled system of nonlinear fractional order differential equations with anti-periodic boundary conditions, Diff. Equ. Appl., 7 (2) (2015), 245-262.

[30] K. SHAH, H. KHALIL AND R. A. KHAN, Investigation of positive solution to a coupled system of impulsive boundary value problems for nonlinear fractional order differential equations, Chaos. Solit. Fract., 77 (2015), 240-246.

[31] S. G. Samko, A. A. Kilbas, And O. I. Marichev, Fractional Integrals and Derivatives: Theory and Applcations, Gordonand Breach, New York, NY, USA, 1993.

[32] M. BENChOHRA, S. HAMANI, AND S. K. NTOUYAS, Boundary value problems for differential equations with fractional order and nonlocal conditions, Nonlinear Analysis: Theo. Method. Appl., 71 (7) (2009), 2391-2396. 